CENDEKIA, Vol. 12. No. 2 Oktober 2018

p-ISSN: 1978-2098; e-ISSN: 2407-8557

Http://cendekia.pusatbahasa.or.id; Email: cendekiaoslo@gmail.com

Center of Language and Cultural Studies, Surakarta, Indonesia

Suprapti, Sri. 2018. Meningkatkan Kemampuan Membaca Cerkak Melalui

Penguasaan Kosa Kata Bahasa Jawa Siswa Kelas VIII SMPN 8 Surakarta.

Cendekia (2018), 12(2): 111-128. DOI:10.30957/Cendekia.v12i2.522.

\title{
MENINGKATKAN KEMAMPUAN MEMBACA CERITA CEKAK \\ MELALUI PENGUASAAN KOSA KATA BAHASA JAWA SISWA KELAS VIII SMPN 8 SURAKARTA
}

\author{
Sri Suprapti \\ SMPN 8 Surakarta \\ JI. HOS Cokroaminoto No. 51 Surakarta \\ Email: suprapti305@yahoo.com
}

\begin{abstract}
This study examines how reading in Javanese short story is improved by the mastery of Javanese vocabulary. The study used Classroom Action Recearch that implemented two cycles, each of which consisted of three meetings. Research was conducted in the ninth graders of SMPN 8 Surakarta involving 32 students. The results show that reading comprehension of Javanese short story substantially increases. Results of test comprehension on reading Javanese short story, task to evaluate short study aspects applied for Javanese short story and effectiveness of classroom activities improve at two cycles, gaining minimum criteria of score that is higher than 75 and classical teaching of $85 \%$. It implies that the function of Javanese vocabulary is pivotal to improve students mastery in reading Javanese texts and provide patterns of how Javanese is implemented.
\end{abstract}

Keywords: Cerkak, Javanese vocabulary, aspects of short story, short story.

DOI:10.30957/Cendekia.v12i2.522.

\section{PENDAHULUAN}

Penelitian Tindakan Kelas (PTK) ini bertujuan untuk mengetahui peningkatan hasil belajar siswa dalam membaca Cerita Cekak (selanjutnya disebut Cerkak) yang ditulis dalam bahasa Jawa dengan teknik menghafal kosa kata bahasa Jawa. Cerkak diambil dari majalah Jawa Panyebar Semangat yang dipublikasikan secara online. Adapun kosa kata bahasa Jawa diambil dari hasil inventarisasi dari pemerhati bahasa Jawa, Larasati yang dimuat dalam web: https://salamadian.com/bahasa-jawa-halus. Website ini dikelola secara resmi oleh Balai Bahasa Jawa Provinsi Yogyakarta.

Seperti juga bahasa daerah di seluruh Nusantara, bahasa Jawa terancam punah walaupun bahasa Jawa masih tercatat sebagai bahasa daerah yang paling banyak penuturnya. Menurut Salahudin (2918) bahasa Jawa adalah bahasa dengan penutur terbanyak di Indonesia, digunakan oleh suku jawa yang wilayahnya meliputi Jawa Tengah, Yogyakarta dan Jawa Timur. Selain itu bahasa jawa juga digunakan oleh sebagian penduduk di wilayah pesisir Karawang, Subang, Cirebon, Indramayu dan 
CENDEKIA, Vol. 12. No. 2 Oktober 2018

p-ISSN: 1978-2098; e-ISSN: 2407-8557

Http://cendekia.pusatbahasa.or.id; Email: cendekiaoslo@gmail.com

Center of Language and Cultural Studies, Surakarta, Indonesia

Suprapti, Sri. 2018. Meningkatkan Kemampuan Membaca Cerkak Melalui

Penguasaan Kosa Kata Bahasa Jawa Siswa Kelas VIII SMPN 8 Surakarta.

Cendekia (2018), 12(2): 111-128. DOI:10.30957/Cendekia.v12i2.522.

Banten di wilayah Jawa Barat. Selain di Jawa, bahasa Jawa digunakan oleh masyarakat di beberapa negara, yaitu Suriname, Aruba, Curacao dan Kaledonia Baru, meskipun jumlah penuturnya tak sebanyak di Suriname yang mayoritas penduduknya ialah suku Jawa.

Bahasa Jawa mengalami kendala pemeliharaan karena secara tertulis hanya sedikit teks berbahasa Jawa. Sumber bacaan berupa esay, opini, Cerkak, Cerbung (beruta bersambung), surat menyurat untuk administrasi, dan novel semakin sedikit tersedia. Hal ini berdampak pada semakin berkurangnya sumber untuk memberi ekposure bahasa Jawa. Generasi muda yang belajar bahasa Jawa hanya mendengar bahasa Jawa dalam tuturan lisan sehingga budaya dan etika yang terkandung dalam bahasa Jawa hilang.

Beruntung, pemerintah daerah telah menerapkan beberapa kebijakan yang memberi peluang bahasa Jawa terus bertahan. Di Jawa Timur, TV yang dikelola Pemilik Jawa Pos asal Magetan, yaitu Dahlan Iskan telah melestarikan bahasa Jawa melalui JTV di bawah Jawa Post sejak era 1990-an. Jangkauan tayangan JTv sampai ke Australia dan di era 2010-an penduduk Indonesia yang bermukim di Australia sering mengobati rasa kangennya dengan menonton JTV ini. Di negara tetangga Malaysia dan Singapura, JTV juga menjadi obat kangen penduduk Jawa yang bermukim di kedua negara tersebut.

Seiring dengan upaya pelestarian bahasa daerah secara nasional pengoperasian TV ini juga dilakukan di Solo dan Yogyakarta. Di Jawa Barat juga dikelola TV dan radio berbahasa Sunda. Di setiap Bandara, misalnya Juanda Surabaya, Adi Sumarmo Solo, Adi Sucipto Yogyakarta, pengumuman kedatangan dan keberangkatan pesawat disampaikan dalam bahasa Indonesia, Bahasa Inggris dan Bahasa Jawa. Hal yang sama dilakukan di Bandara Husen Kartanegara Bandung yang menggunakan bahasa Sunda selain bahasa Indonesia dan bahasa Inggris.

Dalam bentuk tertulis, beruntung majalah bahasa Jawa Panyebar Semangat dan Jayabaya yang terbit di Surabaya masih aktif. Majalah ini menyajikan berita, geguritan, bacaan remaja, dan juga Cerkak. Di Solo, Koran harian yang juga aktif menyajikan tulisan bahasa Jawa mulai dari berita, geguritan dan Cerkak ialah Solo Post. Para pemerhati bahasa Jawa dan guru bahasa Jawa beruntung memperoleh manfaat dari sumber-sumber berbahasa Jawa sebagaimana dikemukakan di atas.

Penelitian ini mencoba mengoptimalkan pembelajaran bahasa Jawa di SMP dengan memanfaatkan media majalah. Peneliti memfokuskan pada proses belajar membaca bahasa Jawa dengan genre Cerkak. Cerkak berkatagori bacaan berbahasa Jawa yang agak sulit karena selain kosa katanya berbahasa Jawa yang jarang digunakan, Cerkak yang dalam bahasa Indonesianya disebut Cerpen termasuk naskah sastra. Namun dengan menganalogikan Cerkak dengan Cerpen tadi, siswa akan memperoleh manfaat secara keilmuwan dan teknis membaca. Selanjutnya, siswa akan lebih bisa fokus mengatasi permaslahan kosa kata bahasa Jawa.

Untuk menjembati permasalahan tersebut, peneliti telah mengadaptasi kumpulan Kosa Kata bahasa Jawa yang dipublikasikan oleh Pusat Bahasa Jawa Yogyakarta 
CENDEKIA, Vol. 12. No. 2 Oktober 2018

p-ISSN: 1978-2098; e-ISSN: 2407-8557

Http://cendekia.pusatbahasa.or.id; Email: cendekiaoslo@gmail.com

Center of Language and Cultural Studies, Surakarta, Indonesia

Suprapti, Sri. 2018. Meningkatkan Kemampuan Membaca Cerkak Melalui

Penguasaan Kosa Kata Bahasa Jawa Siswa Kelas VIII SMPN 8 Surakarta.

Cendekia (2018), 12(2): 111-128. DOI:10.30957/Cendekia.v12i2.522.

(2018). Kosa kata bahasa Jawa itu ditulis oleh Larasati (2017) sebagai hasil dokumentasi daftar kata bahasa Jawa yang aktif digunakan lapisan masyarakat Jawa untuk bertutur harian. Daftar kosa kata bahasa Jawa tersebut disajikan dalam table 1 .

Tabel 1. Kosa kata bahasa Jawa yang sering digunakan untuk tuturan harian (Larasati, 2017) dikutip dari: https://salamadian.com/bahasa-jawa-halus/

\begin{tabular}{|c|c|c|c|}
\hline \multicolumn{4}{|c|}{ No Bahasa IndonesiaBahasa Jawa NgokoBahasa Krama Inggil } \\
\hline 1 & Saya & Kulo & Dalem \\
\hline 2 & Kamu & Kowe & Panjenengan \\
\hline 3 & Kami & Awakedhewe & Kito \\
\hline 4 & Dia & Deweke & Piyambakipun \\
\hline 5 & Ini & Iki & Meniko \\
\hline 6 & Itu & Kui & Niku \\
\hline 7 & Apa & Opo & Menopo \\
\hline 8 & Kapan & Kapan & Kapan \\
\hline 9 & Dimana & Ngendhi & Wonten Pundhi \\
\hline 10 & Yang Mana & Singendhi & Ingkangpundhi \\
\hline 11 & Siapa & Sopo & Sinten \\
\hline 12 & Mengapa & Ngopo & Kadhosmenopo \\
\hline 13 & Bagaimana & Piye & Kadhospundi \\
\hline 14 & $\mathrm{Ya}$ & Yoh & Inggih/Injih \\
\hline 15 & Tidak & Ora & Mboten \\
\hline 16 & Barangkali & Menowo & Menawi \\
\hline 17 & Satu & Siji & Setunggal \\
\hline 18 & Dua & Loro & Kalih \\
\hline 19 & Tiga & Telu & Tigo \\
\hline 20 & Empat & Papat & Sekawan \\
\hline 21 & Lima & Limo & Gangsal \\
\hline 22 & Sepuluh & Sedasa & Sedoso \\
\hline 23 & Seratus & Satus & Setunggalatus \\
\hline 24 & Seribu & Sewu & Setunggalewu \\
\hline 25 & Orang & Uwong & Tiyang/Piyantun \\
\hline 26 & Laki-Laki & Lanang & Kakong \\
\hline 27 & Perempuan & Wedhok/Wadhon & Estri \\
\hline 28 & Ayah & Rama & Romo \\
\hline 29 & Ibu & Ibu & Ibu \\
\hline 30 & Anak & Lare/Putra & Putro \\
\hline 31 & Nama & Jeneng/Asma & Asmo \\
\hline 32 & Uang & Duwit & Artho \\
\hline 33 & Kamar Kecil & (Kamar) Mburi & (Kamar) Wingking \\
\hline 34 & Air & Banyu & Toya \\
\hline
\end{tabular}


CENDEKIA, Vol. 12. No. 2 Oktober 2018

p-ISSN: 1978-2098; e-ISSN: 2407-8557

Http://cendekia.pusatbahasa.or.id; Email: cendekiaoslo@gmail.com

Center of Language and Cultural Studies, Surakarta, Indonesia

Suprapti, Sri. 2018. Meningkatkan Kemampuan Membaca Cerkak Melalui

Penguasaan Kosa Kata Bahasa Jawa Siswa Kelas VIII SMPN 8 Surakarta.

Cendekia (2018), 12(2): 111-128. DOI:10.30957/Cendekia.v12i2.522.

\begin{tabular}{|c|c|c|}
\hline 35 Jalan & Dalan & Mergi \\
\hline 36 Kira-Kira & Kiro-Kiro & Kinten-Kinten \\
\hline 37 Semua & Kabeh & Sedanten/Sedaya \\
\hline 38 Kalau/Jika & Menowo & Menawi \\
\hline 39 Lebih & Luwih & Langkung \\
\hline 40 Sangat/Sekali & Banget & Sanget \\
\hline 41 Dari & Seko & Saking \\
\hline $42 \mathrm{Ke}$ & Dateng & Dateng \\
\hline 43 Sekarang & Saiki & Sakmeniko \\
\hline 44 Baru & Anyar & Enggal \\
\hline 45 Tua & Tuwo & Sepuh \\
\hline 46 Panjang & Dowo & Panjang \\
\hline 47 Pendek & Cendek & Cendak \\
\hline 48 Murah & Merah & Mirah \\
\hline 49 Mahal & Larang & Awis \\
\hline 50 Panas & Benther & Benther \\
\hline 51 Dingin & Adem & Asrep \\
\hline 52 Kemarin & Wingi & Kolowingi \\
\hline 53 Hari Ini & Saiki & Sakmeniko \\
\hline 54 Besok & Sesuk & Mbenjang \\
\hline 55 Atas & Nduwur & Nginggil \\
\hline 56 Bawah & Ngisor & Ngandhap \\
\hline 57 Lapar & Ngelih & Luwe \\
\hline 58 Bahagia & Seneng & Rahayu \\
\hline 59 Sakit & Lara & Gerah \\
\hline 60 Maaf & Ngapunten & Ngapura/Ngapuro \\
\hline 61 Pagi & Esuk & Enjing-Injing \\
\hline 62 Siang & Awan & Siang \\
\hline 63 Malam & Bengi & Dalu/Ndalu \\
\hline 64 Apa Kabar & Piyekabare & Pripun/Kadospundi \\
\hline 65 Berapa & Piro & Pinten \\
\hline 66 Silahkan & Monggo & Monggopunaturi \\
\hline 67 Terima Kasih & Muwun & Maturnuwun \\
\hline 68 Selamat Jalan & Segeng Tindak & Sugeng Tindak \\
\hline 69 Belum & Durung & Dereng \\
\hline 70 Karena & Sebabe/Mergo & Amargi \\
\hline 71 Tetapi & Mergane & Amargi \\
\hline 72 Disini & Nangkene & Wontenmriki \\
\hline 73 Baik & Apik & $\mathrm{Sae}$ \\
\hline 74 Jelek & Elek & Kirangsae \\
\hline 75 Betul & Bener & Leres \\
\hline 76 Cantik/Indah & Apik & Endah \\
\hline
\end{tabular}


CENDEKIA, Vol. 12. No. 2 Oktober 2018

p-ISSN: 1978-2098; e-ISSN: 2407-8557

Http://cendekia.pusatbahasa.or.id; Email: cendekiaoslo@gmail.com

Center of Language and Cultural Studies, Surakarta, Indonesia

Suprapti, Sri. 2018. Meningkatkan Kemampuan Membaca Cerkak Melalui

Penguasaan Kosa Kata Bahasa Jawa Siswa Kelas VIII SMPN 8 Surakarta.

Cendekia (2018), 12(2): 111-128. DOI:10.30957/Cendekia.v12i2.522.

\begin{tabular}{|c|c|c|}
\hline 77 Besar & Gedhe & Ageng \\
\hline 78 Kecil & Cilik & Alit \\
\hline 79 Banyak & Akeh & Kathah \\
\hline 80 Sedikit & Sithik & Sakedhik \\
\hline 81 Sama & Podho & Sami \\
\hline 82 Bisa & Iso & Saget \\
\hline 83 Punya & Duwe & Kagungan \\
\hline 84 Ada & Ana & Wonten \\
\hline $85 \mathrm{Mau}$ & Gelem & Kersa \\
\hline 86 Jangan & Ojo & Ampun \\
\hline 87 Pergi & Lungo & Tindhak \\
\hline 88 Datang & Teko & Rawuh \\
\hline 89 Berjalan & Mlaku & Mlampah \\
\hline 90 Bicara & Omong & Ngendika/Ngendiko \\
\hline 91 Bilang & Ngomong & Dawuh \\
\hline 92 Lihat & Ndelok & Mrisani \\
\hline 93 Mengerti & Ngerti & Ngertos \\
\hline 94 Makan & Mangan & Dahar/Nedo \\
\hline 95 Minum & Ngombe & Ngunjuk \\
\hline 96 Dengar & Krungu & Miereng \\
\hline 97 Tahu & Ngerti & Ngertos \\
\hline 98 Kasi & Wenehi & Paringi \\
\hline 99 Suka & Seneng & Remen \\
\hline 100Cinta & Seneng & Tresna/Tresno \\
\hline 101Pikir & Pikir & Penggalih \\
\hline 102Membuat & Nggawe & Nadamel/Damel \\
\hline 103Duduk & Lungguh & Lenggah/Pinarak \\
\hline 104Potong & Tugel & Potong \\
\hline 105Beli & Tuku & Tumbas \\
\hline 106Berhenti & Mangdheg & Kendhel \\
\hline 107Jauh & Adoh & Tebeh \\
\hline 108Dekat & Cedak & Cerak \\
\hline 109Kanan & Tengen & Tengen \\
\hline 110Kiri & Kiwo & Kiwo \\
\hline
\end{tabular}

Terkait dengan pembelajaran membaca, peneliti mengutip pendapat Akhadiah (1992:29) yang mengatakan melalui pembelajaran membaca, guru dapat mengembangkan nilai-nilai moral, kemampuan bernalar dan kualitas anak didik. Menurut Akhadiyah (2991) membaca melibatkan penguasaan gramatika, kosa kata dan merangkai makna. Proses membaca terdiri dari beberapa aspek. Aspek-aspek tersebut adalah: 
CENDEKIA, Vol. 12. No. 2 Oktober 2018

p-ISSN: 1978-2098; e-ISSN: 2407-8557

Http://cendekia.pusatbahasa.or.id; Email: cendekiaoslo@gmail.com

Center of Language and Cultural Studies, Surakarta, Indonesia

Suprapti, Sri. 2018. Meningkatkan Kemampuan Membaca Cerkak Melalui

Penguasaan Kosa Kata Bahasa Jawa Siswa Kelas VIII SMPN 8 Surakarta.

Cendekia (2018), 12(2): 111-128. DOI:10.30957/Cendekia.v12i2.522.

- Aspek Sensori, yaitu kemampuan untuk memahami simbol-simbol tertulis,

- Aspek Perseptual, yaitu kemampuan untuk menginterpresentasikan apa yang dilihat sebagai simbol.

- Aspek Skemata, yaitu kemampuan menghubungkan informasi tertulis dengan struktur pengetahuan yang telah ada.

- Aspek Berpikir, yaitu kemampuan membuat inferensi dan evaluasi dari materi yang dipelajari.

- Aspek Afektif, yaitu aspek yang berkenaan dengan minat pembaca yang berpengaruh terhadap kegiatan membaca.

Menurut Amir (1996:2) pembelajaran membaca tidak cukup hanya menghafal kalimat; jika teks yang dilafalkan maka pembelajarannya jelas dan fasih, tepat informasi dan penjedaannya, sehingga komunikatif dengan pendengar, dan juga ditandai oleh suatu pemahaman teks. Membaca adalah melihat serta memahami isi dari apa yang tertulis dengan melisankan atau hanya di hati (Tim Penyusun Kamus Pusat Pembinaan dan Pengembangan Bahasa Indonesia, 2002:18). Menurut Ronald Barker dan Robert Ekskarpit (1975:155), membaca merupakan penangkapan dan pemahaman ide, aktifitas pembaca yang diiringi curahan jiwa dalam menghayati naskah. Setelah proses yang bersifat mekanis tersebut berlangsung, maka nalar dan intuisi kita bekerja pula, berupa proses pemahaman dan penghayatan. Dengan penghayatan, pembaca berarti telah pula merasakan nuansa naskah sehingga bisa pula melangsungkan perenungan. Membaca adalah suatu proses yang dilakukan serta digunakan oleh pembaca untuk memperoleh pesan, yang hendak disampaikan oleh penulis melalui media kata-kata atau bahasa tulis. (Tarigan, 1985:7).

Sehubungan dengan membaca bahasa Jawa, informasi yang diperoleh dari guru SMPN 8 Surakarta dan guru yang terlibat dalam MGMP Bahasa Jawa se Surakarta bisa diketaui bahwa: jumklah kosa kata bahasa Jawa yang dikuasai siswa terbatas, siswa kurang memiliki figur penggunaan bahasa Jawa, untuk bahasa tulis siswa kuraang mengerti penggunaan unggah-ungguh sehingga kompetensi pragmatik siswa kurang, siswa kekurangan sumber tertulis yang bisa memperkaya penggunaan bahasa Jawa; jira terdapat teks bahasa Jawa, gramática dan kosa katanya terlalu tinggi karena berisi krama inggil atau tertulis dalam huruf Jawa yang secara umum siswa masih asing.

Untuk mengatasi hal tersebut, peneliti telah mengupayakan peningkatan kemampuan membaca teks bahasa Jawa di kelas. Sebelumnya, peneliti meneliti bagaimana teks legenda digunakan untuk meningkatkan kemampuan membaca bahasa Jawa (Suprapti, 2017). Kali ini, peneliti mengolah penggunaan kosa kata bahasa Jawa untuk meningkatkan kemampuan membaca Cerkak. Untuk itu, peneliti melakukan penelitian berjudul: "Penggunaan kosa kata bahasa Jawa untuk meningkatkan penguasaan membaca Cerkak siswa kelas VIII SMPN 8 Surakarta".

Murahim (2014:93) mengatakan cerpen atau cerita pendek adalah karangan pendek berbentuk prosa. Ayip dalam Badrun (1983:101) berpendapat cerita pendek atau 
CENDEKIA, Vol. 12. No. 2 Oktober 2018

p-ISSN: 1978-2098; e-ISSN: 2407-8557

Http://cendekia.pusatbahasa.or.id; Email: cendekiaoslo@gmail.com

Center of Language and Cultural Studies, Surakarta, Indonesia

Suprapti, Sri. 2018. Meningkatkan Kemampuan Membaca Cerkak Melalui

Penguasaan Kosa Kata Bahasa Jawa Siswa Kelas VIII SMPN 8 Surakarta.

Cendekia (2018), 12(2): 111-128. DOI:10.30957/Cendekia.v12i2.522.

cerpen merupakan suatu kebulatan ide. Nurgiyantoro (2013:12) menegaskan cerpen adalah sebuah cerita yang dibaca dalam sekali duduk, berkisar setengah sampai dua jam. Jadi, cerpen adalah suatu bentuk karya sastra berupa karangan fiktif yang berisi tentang kehidupan seseorang penulis atau kehidupan yang diceritakan secara ringkas dan difokuskan hanya pada satu tokoh saja yang dituangkan dalam bentuk tulisan.

Rosidi dalam Badrun (1983:101) mengemukakan enam ciri cerpen, yaitu: (1) mengandung interprestasi pengarang tentang kehidupan, baik secara langsung atau tidak langsung, (2) harus menimbulkan satu efek dalam pikiran pembaca dan juga harus menarik perhatian, (3) mengandung detail dan insiden yang dipilih dengan sebagai dan dapat menimbulkan pertanyaan dalam pikiran pembaca, (4) dikuasai oleh sebuah insiden, (5) harus ada seorang pelaku utama, dan (6) menyajikan satu kesan tunggal. Adapun Murahim (2014:93) mengemukakan ciri-ciri cerpen:

- Bersumber dari pengalaman sendiri atau orang lain.

- Bentuk tulisannya padat, singkat, dan lebih pendek dari novel.

- Terdiri kurang dari 10.000 kata.

- Penokohannya sederhana, singkat dan tidak mendalam.

- Menceritakan satu kejadian, dan terjadinya perkembangan jiwa dan krisis, tetapi tidak menimbulkan perubahan nasib.

Adapun unsur-unsur intrinsik cerpen tersebut menurut Mustofa (2011:9) adalah:

- Tema, persoalan yang menduduki tempat utama dalam karya sastra.

- Alur/plot, rangkaian peristiwa yang memiliki hubungan sebab akibat sehingga menjadi satu kesatuan yang padu bulat dan utuh.

- Amanat, dalah pemecahan yang diberikan oleh pengarang bagi persoalan bagi persoalan di dalam karya sastra.

- Latar/setting, tempat atau waktu terjadinya peristiwa-peristiwa yang terjadi dalam sebuah karya sastra.

- Sudut pandang, cara pengarang menempatkan dirinya dalam sebuah cerita atau karya sastra.

- Tokoh, pelaku dalam karya sastra.

- Penokohan/perwatakan, teknik atau cara-cara menampilkan tokoh.

Sintaksis pembelajaran membaca Cerkak ini menyandarkan pada kerja kelompok kecil 2 anggota dalam satu kelompok. Tujuh langkah utama atau fase dalam pembelajaran Cerkak disajikan pada Tabel 2.

Tabel 2. Sintaks/Langkah Pembelajaran Membaca Cerkak

Fase Tingkah Laku Guru


CENDEKIA, Vol. 12. No. 2 Oktober 2018

p-ISSN: 1978-2098; e-ISSN: 2407-8557

Http://cendekia.pusatbahasa.or.id; Email: cendekiaoslo@gmail.com

Center of Language and Cultural Studies, Surakarta, Indonesia

Suprapti, Sri. 2018. Meningkatkan Kemampuan Membaca Cerkak Melalui

Penguasaan Kosa Kata Bahasa Jawa Siswa Kelas VIII SMPN 8 Surakarta.

Cendekia (2018), 12(2): 111-128. DOI:10.30957/Cendekia.v12i2.522.

Fase 1

Menyampaikan tujuan dan memotivasi siswa

Guru menyampaikan tujuan pelajaran yang ingin dicapai pada pembelajaran tersebut dan memotivasi siswa belajar.

Fase 2

Menyajikan informasi

Guru memberikan informasi mengenai Cerkak

Fase 3

Mengorganisasikan siswa ke dalam ke Guru membantu membentuk kelompok bel

lompok belajar

ajar dan memberi motivasi agar kelom

pok-kelompok belajar tersebut melaku

kan tugas dengan baik.

Fase 4

Menyajikan alat peraga

Guru menayangkan isi Cerkak dan kosa

kata

Fase 5

Membimbing kelompok-kelompok Guru membimbing kelompok-kelompok bel

belajar dalam mengerjakan tugas. ajar pada saat mereka mengerjakan tugas.

Fase 6

Evaluasi

Guru mengevaluasi hasil belajar kelompok siswa, dan tiap-tiap kelompok menyampai kan hasil diskusinya.

Fase 7

Refleksi

Guru berusaha menghargai hasil pekerjaan siswa baik secara individu maupun kelom pok dengan berbagai cara.

\section{METODE}

\subsection{Jenis Penelitian}

Penelitian ini dilakukan di SMPN 8 Surakarta Jl. HOS Cokrroaminoto 51 Surakarta. Sampel penelitian ini adalah siswa kelas VIII-A, berjumlah siswa 32, untuk mata pelajaran Bahasa Jawa, dengan tema Cerita Pendek (Cerkak).

PTK dilaksanakan dalam dua siklus. Tiap-tiap siklus dilaksanakan sesuai dengan perubahan partisipasi dan kompetensi yang dicapai, berdasarkan perencanaan yang disusun. Kompetensi dan hasil belajar siswa diidentifikasi melalui observasi selama pembelajaran berlangsung. Peneliti dibantu oleh 2 observer mata pelajaran yang sama. Peneliti maupun observer dapat menggunakan lembaran observasi sehingga keaktifan 
CENDEKIA, Vol. 12. No. 2 Oktober 2018

p-ISSN: 1978-2098; e-ISSN: 2407-8557

Http://cendekia.pusatbahasa.or.id; Email: cendekiaoslo@gmail.com

Center of Language and Cultural Studies, Surakarta, Indonesia

Suprapti, Sri. 2018. Meningkatkan Kemampuan Membaca Cerkak Melalui

Penguasaan Kosa Kata Bahasa Jawa Siswa Kelas VIII SMPN 8 Surakarta.

Cendekia (2018), 12(2): 111-128. DOI:10.30957/Cendekia.v12i2.522.

siswa dapat terkontrol dan hasil observasi serta produk pembelajaran dapat dijadikan bahan kajian untuk meningkatkan proses pembelajaran.

\subsection{Instrumen Penelitian dan Teknik Pengumpulan Data}

Alat-alat yang digunakan untuk mengumpulkan data keberhasilan belajar siswa adalah: tes tertulis, observasi, dan penilaian produk. Tes membaca dilakukan oleh siswa dalam menjawab pertanyaan hasil bacaan dua Cerkak yang disediakan guru. Pertanyaan membaca Cerkak menanyakan tentang tujuh aspek dalam Cerkak yang tercakup dalam penilaian produk. Pertanyaan berbentuk uraian berisi apa, siapa dan mengapa. Penilaian proses diukur dengan instrumen lembar observasi untuk mengetahui tingkat aktifitas siswa. Selain menjawab pertanyaan, siswa diberi teks Cerkak dan diminta memberi penjelasan mengenai aspek yang dinilai dalam penilaian produk yang meliputi:

- tema

- penokohan

- alur

- latar

- gaya penceritaan

- kepaduan

- kesan

Jadi data mengenai aspek dalam Cerkak dikumpulkan melalui tes membaca Cerkak. Data mengenai keaktifan siswa dalam belajar dikumpulkan melalui daftar cek pengamatan aktifitas siswa. Adapun data mengenai keaktifan guru dikumpulkan melalui angket pengamatan guru.

\subsection{Pemberian Tindakan}

Penelitian ini menggunakan dua judul Cerkak yaitu: Sepure Wis Mangkat dan Botol Plastik untuk memberikan tindakan dalam penelitian. Kedua Cerkak tersebut diunduh dari laman majalah Panyebar Semangat Online. Judul yang dipilih tersebut tidak bercerita mengenai kehidupan anak sekolah karena Cerkak yang tersedia hanya mencerikan kehidupan orang dewasa. Meskipun bercerita tetang roman, tetapi peneliti memilih kisah yang tidak vulgar yang menceritakan percintaan sehingga imaginasi siswa masih terkontrol untuk mendapat nilai dan pesan positif.

Penelitian ini terdiri dari dua siklus dan setiap siklus dilaksanakan selama tiga tatap muka. Pada siklus I, tatap muka pertama dan kedua digunakan untuk membahas Cerkak berjudul Sepure Wis Mangkat. Pertemuan ketiga digunakan untuk tes membaca pemahaman Cerkak. Pada siklus II, siswa diberi tindakan dengan membaca Cerkak berjudul Botol Plastik. Seperti pada siklus I, siklus II ini juga terdiri dari tiga tatap muka, dua tatap muka untuk membahasa Cerkak berjudul Botol Plastik dan tatap muka ketiga digunakan untuk tes membaca Cerkak. 
CENDEKIA, Vol. 12. No. 2 Oktober 2018

p-ISSN: 1978-2098; e-ISSN: 2407-8557

Http://cendekia.pusatbahasa.or.id; Email: cendekiaoslo@gmail.com

Center of Language and Cultural Studies, Surakarta, Indonesia

Suprapti, Sri. 2018. Meningkatkan Kemampuan Membaca Cerkak Melalui

Penguasaan Kosa Kata Bahasa Jawa Siswa Kelas VIII SMPN 8 Surakarta.

Cendekia (2018), 12(2): 111-128. DOI:10.30957/Cendekia.v12i2.522.

Tindakan pada siklus I diberikan dalam bentuk siswa diberi tugas membaca Cerkak Sepure Wis Mangkat. Setelah itu, siswa diminta memberi penilaian tentang 7 aspek Cerkak. Setelah siswa memberi penilaian, siswa diberi pertanyaan pendalaman mengenai isi Cerkak. Jawaban diberikan secara tertulis dan secara lisan. Demikian juga pada siklus II, siswa diberi Cerkak berjudul Botol Plastik dan diberi tes tulis dan tes lisan untuk membaca pemahaman isi Cerkak.

Selama tatap muka berlangsung, guru dan guru kolaborator mengamati aktifitas siswa. Saat guru peneliti mengajar, guru kolaborator mengadakan pengamatan tindakan guru peneliti. Di akhir pertemuan, guru peneliti dan guru kolaborator mengoreksi jawaban siswa, menganalisis hasil observasi dan membuat refleksi akhir untuk mengetahui kelamahan, keunggulan dan hal-hal yang belum muncul pada siklus I kemudian menyusun perencanaan tujuan pembelajaran dan materi ajar yang digunakan dalam siklus II. Penelitian ini diakhiri pada siklus II karena hasil tes dan refleksi pada siklus II sudah mencapai KKM, yaitu nilai siswa 75 dan aktifitas pembelaajaran 75\%.

\subsection{Teknik Analisis Data}

Ketuntasan belajar siswa diukur dengan ketuntasan komulatif ketujuh aspek tersebut. Data dianalisis menggunakan statistik deskriptif berupa frekwensi dan persentase. Data berupa skor diklasifikasi menurut katagorinya dan dianalisis rerata serta persentasenya. Ketuntasan belajar individual ditetapkan minimal 75\%, untuk klasikal 85\% sesuai dengan ketentuan yang diberlakukan di sekolah. Beberapa hal yang diteliti dalam rangka peningkatan membaca Cerkak antara lain:

- Siswa, yaitu keaktifan dan partisipasai siswa dalam mengikuti pelajaran meningkat dengan ditandai diskusi berlangsung baik, mengerjakan tugas, menyampaikan hasil tugas.

- Guru, kemampuan dan keterampilan guru dalam mengembangkan strategi pem belajaran yang melibatkan siswa secara merata baik secara individu maupun kelompok.

- Proses pembelajaran, yaitu proses yang terjadi selama pembelajaran berlangsung, meliputi aktivitas siswa, guru, dan interaksi guru dengan siswa maupun siswa dengan siswa.

Penelitian ini dikatakan berhasil apabila guru sudah dapat melaksanakan pembelajaran dengan baik. Siswa berpartisipasi aktif dalam proses belajar mengajar, dan dapat menunjukkan unjuk kerja yang positif dalam penelitian, dan peningkatan hasil evaluasi.

\section{HASIL DAN BAHASAN}


CENDEKIA, Vol. 12. No. 2 Oktober 2018

p-ISSN: 1978-2098; e-ISSN: 2407-8557

Http://cendekia.pusatbahasa.or.id; Email: cendekiaoslo@gmail.com

Center of Language and Cultural Studies, Surakarta, Indonesia

Suprapti, Sri. 2018. Meningkatkan Kemampuan Membaca Cerkak Melalui

Penguasaan Kosa Kata Bahasa Jawa Siswa Kelas VIII SMPN 8 Surakarta.

Cendekia (2018), 12(2): 111-128. DOI:10.30957/Cendekia.v12i2.522.

Hasil penelitian pada siklus I dan siklus II dilaporkan dalam bentuk skor tes membaca Cerkak, hasil penilaian guru terhadap hasil membaca siswa, dan hasil observasi aktifitas pembelajaran.

\subsection{Capaian Nilai Membaca Cerkak secara Kelompok}

Nilai rerata hasil tes membaca Cerkak 32 siswa pada siklus I dilaporkan pada Tabel 3.

Tabel 3. Distribusi Nilai Hasil Tes Membaca Cerkak

\begin{tabular}{lcccccc}
\hline No & Interval Nilai & \multicolumn{2}{c}{ Siklus I } & \multicolumn{2}{c}{ Siklus II } & Kategori \\
\hline & & $\begin{array}{c}\text { Jumlah } \\
\text { N=32 }\end{array}$ & Persentase & $\begin{array}{r}\text { Jumlah } \\
\mathrm{N}=32\end{array}$ & Persentase & \\
\hline 1. & $90-100$ & - & - & 1 & 3.1 & Istimewa \\
\hline 2. & $80-89$ & 3 & 9.38 & 6 & 18.75 & Amat baik \\
\hline 3. & $75-79$ & 12 & 37.5 & 20 & 62.50 & Baik \\
\hline 4. & $<75$ & 17 & 53.13 & 5 & 15.63 & Belum lulus \\
\hline \multicolumn{7}{c}{} \\
\hline
\end{tabular}

Tabel 3 menunjukkan bahwa terjadi peningkatan yang cukup tinggi dalam siklus I dan siklus II. Pada siklus I, terdapat 25 (48.86\%) siswa mencapai KKM dan 17 $(53.13 \%)$ tidak lulus. Kriteria penilaian ini memudahkan evaluasi karena siswa diidentifikasi dalam capaian lulus dan belum lulus. Kriteria lulus apabila siswa memperoleh skos 75-100 dan yang belum sampai 75 disebut belum lulus.

Pada siklus II, diketahui hanya $5(15.63 \%)$ siswa yang nilai tesnya kurang dari 75. Kelima siswa tersebut belum mencapai KKM dan dinyatakan belum lulus. Adapun sebanyak $27(84,38 \%)$ dinyatakan lulus. Dengan $\mathrm{KKM}=75$, terdapat $20(62.50 \%)$ siswa dinyatakan lulus baik, $6(18,75 \%)$ lulus amat baik, dan $1(3,1 \%)$ lulus Istimewa.

Hasil wawancara menunjukkan bahwa siswa yang memperoleh nilai baik, amat baik dan istimewa menyatakan tiap hari di rumah berbahasa Jawa, membaca pesan misalnya SMS dari orang tua dan teman menggunakan bahasa Jawa, dan frekwensi membaca teks berbahasa Jawa dalam sehari antara 3 kali.

\subsection{Capaian Penilaian Aspek Cerkak}

Hasil tes membaca Cerkak dengan jenis tugas siswa secara kelompok menilai aspek Cerkak disajikan dalam tabel 4. Ketujuh aspek Cerkak tersebut ialah: tema, penokohan, alur, latar, kepaduan, gaya penceritaan, kesan. Satu kelompok terdiri dari 2 orang sehingga jika kelas berisi 32 orang diperoleh 16 kelompok. Penilaian dilakuan dengan cara mengidentifikasi jawaban benar pada setiap aspek. Jawaban benar diberi skor 1 dan tidak benar 0. Dengan demikian, kemunculan frekwensi jawaban benar merepresentasikan ketuntasan atau ketidaktuntasan hasil belajar.

Tabel 4. Ketercapaian Nilai Aspek Cerpen Kelompok 
CENDEKIA, Vol. 12. No. 2 Oktober 2018

p-ISSN: 1978-2098; e-ISSN: 2407-8557

Http://cendekia.pusatbahasa.or.id; Email: cendekiaoslo@gmail.com

Center of Language and Cultural Studies, Surakarta, Indonesia

Suprapti, Sri. 2018. Meningkatkan Kemampuan Membaca Cerkak Melalui

Penguasaan Kosa Kata Bahasa Jawa Siswa Kelas VIII SMPN 8 Surakarta.

Cendekia (2018), 12(2): 111-128. DOI:10.30957/Cendekia.v12i2.522.

\begin{tabular}{llllll}
\hline No & Aspek yang Dinilai & \multicolumn{3}{c}{ Siklus I } & \multicolumn{2}{c}{ Siklus II } \\
\hline & & Jumlah & Persentase & Jumlah & Persentase \\
\hline & $\mathrm{N}=16$ & & $\mathrm{~N}=16$ \\
\hline 1. & Tema & 15 & 93.75 & 16 & 100 \\
\hline 2. & Penokohan & 12 & 75.00 & 13 & 81.25 \\
\hline 3. & Alur & 6 & 37.50 & 10 & 62.50 \\
\hline 4. & Latar & 10 & 62.50 & 12 & 75.00 \\
\hline 5. & Kepaduan & 11 & 68.75 & 12 & 75.00 \\
\hline 6. & Gaya Penceritaan & 11 & 68.75 & 12 & 75.00 \\
\hline 7. & Kesan & 10 & 62.50 & 10 & 62.50 \\
\hline
\end{tabular}

Data pata tabel 4 menunjukkan bahwa pada siklus I, frekwensi terendah ialah alur yang dijawab benar oleh 6 kelompok (37.50\%) dan tertinggi diperoleh dari aspek tema yang dijawab benar oleh 15 kelompok (93.75\%). Ini menunjukkan bahwa pemahaman aspek Cerkak memiliki tingkat kesulitan yang beragam ketiga siswa baru diperkenalkan mengenai aspek Cerkak dan bagamana memahami isi Cerkak.

Pada siklus II, terjadi peningkatan pada pemahaman hampir semua aspek. Dengan demikian capaian siswa dalam membaca pemahaman Cerkak sudah memenuhi KKM dan tindakan tidak perlu dilanjutkan lagi. Namun demikian penting untuk diketahui bahwa dari tujuh aspek Cerkak, tidak semua memuaskan dan jawaban mencapai KKM. Data pada tabel 2 menunjukkan bahwa aspek alur dan kesan belum dikuasai dengan baik karena kelompok yang menjawab benar pada kedua aspek tersebut masing-masing hanya $10(62.25 \%)$. Angka 10 kelompok ini sudah bagus tetapi jumlahnya belum mencapai kriteria minimal $75 \%$.

\subsection{Nilai Kumulatif Individu dan Klasikal}

Nilai persentase kumulatif ketuntasan belajar secara invidu disajikan pada tabel 5 dan efektifitas pembelajaran siswa disajikan pada tabel 6 .

Tabel 5. Persentase Nilai Kumulatif Ketuntasan Belajar Klasikal

\begin{tabular}{|c|c|c|c|c|c|}
\hline & \multirow[t]{2}{*}{ Ketuntasan Belajar } & \multicolumn{2}{|c|}{ Siklus I } & \multicolumn{2}{|c|}{ Siklus II } \\
\hline & & Jumlah & $\begin{array}{l}\text { Persentase } \\
\mathrm{N}=32\end{array}$ & Jumlah & $\begin{array}{l}\text { Persentase } \\
=32\end{array}$ \\
\hline 1. & Ketuntasan Belajar & 20 & 62.5 & 28 & 87.5 \\
\hline 2. & Ketidaktuntasan Belajar & 14 & 43.75 & 6 & 18.75 \\
\hline
\end{tabular}

Data pada tabel 5 menunjukkan bahwa pada siklus I siswa yang belajar tuntas secara klasikal ialah 20 orang $(62.5 \%)$. Capaian ini masih jauh dari cukup untuk KKM 
CENDEKIA, Vol. 12. No. 2 Oktober 2018

p-ISSN: 1978-2098; e-ISSN: 2407-8557

Http://cendekia.pusatbahasa.or.id; Email: cendekiaoslo@gmail.com

Center of Language and Cultural Studies, Surakarta, Indonesia

Suprapti, Sri. 2018. Meningkatkan Kemampuan Membaca Cerkak Melalui

Penguasaan Kosa Kata Bahasa Jawa Siswa Kelas VIII SMPN 8 Surakarta.

Cendekia (2018), 12(2): 111-128. DOI:10.30957/Cendekia.v12i2.522.

pembelajaran klasikal 85\%. Penelitian ini menunjukkan bahwa capaian belajar klasikal pada siklus II terlampaui, yaitu 28 (87.5\%) siswa berhasil secara klasikal.

Untuk lebih memastikan lagi tingkat keberhasilan PTK ini, berikut disajikan hasil analisis keaktifan siswa dalam pembelajaran di kelas pada tabel 6 .

Tabel 6. Keaktifan Siswa

\begin{tabular}{llclll}
\hline No & Keaktifan Siswa & \multicolumn{2}{c}{ Siklus I } & \multicolumn{2}{c}{ Siklus II } \\
\hline \multicolumn{2}{l}{ Persentase } & Jumlah & Persentase & & Jumlah \\
\hline 1. & Siswa yang aktif & 19 & 59.37 & 26 & 81.25 \\
\hline 2. & Siswa yang kurang aktif & 13 & 40.63 & 6 & 18.75 \\
\hline & 32 & & 32 & \\
\hline
\end{tabular}

\section{SIMPULAN}

Secara umum penelitian ini menunjukkan hasil bahwa penggunaan kosa kata bahasa Jawa memberi kontribusi penting dalam meningkatkan kemampuan membaca Cerkak. Hasil analisis ketuntasan belajar individu dan klasikal menunjukkan bahwa pemampuan siswa membaca Cerkak meningkat setelah siswa diberi tindakan baik berupa hapalan makna kata maupun penggunaan kata secara konteks dalam membaca Cerkak. Penelitian ini secara khusus menunjukkan hasil bahwa peningkatan kemampuan membaca Cerkak mengalami peningkatan dilihat berdasarkan beberapa kriteria: (1) tes hasil membaca pemahaman Cerka, (2) tugas membaca Cerkak dan menilai aspek dalam Cerkak, (3) nilai ketuntasan membaca, dan (4) keaktifan siswa dalam proses belajar mengajar. Faktor penting keberhasilan penelitian ini ialah siswa diberi skposure kosa kata bahasa Jawa dan teks Cerkak. Faktor lain ialah penggunaan materi ajar otentik berupa Cerkak yang ditulis oleh penulis Cerkak dan diunduh secara online. Selain membaca teks yang disajikan guru, siswa juga bisa mengunduh secara online Cerkak yang dimaksudkan.

\section{DAFTAR PUSTAKA}

Alwi, Z. 1999. Peningkatan Mutu Pembelajaran Bahasa Indonesia melalui Model Integratif. Prosiding Seminar Hasil-Hasil Penelitian Peran IPTEKdalam Menciptakan Masyarakat yang maju dan Mandiri. Lemlit Unsri, Inderalaya 31 maret 1999

Alwasilah, A. Chaedar dan Senny Susana Alwasilah. 2005. Pokoknya Menulis. Bandung: PT. Kiblat Buku Utama.

Akhadiah MK, S. dkk. 1997. Materi Pokok Menulis I. Jakarta: UT.

Anderson, R.C. dan Pearson, D. 1984. A. Schema Theoritic View of Basic Process in Reading Comprehension. Dalam David Pearson (ed.), Handbook of Reading Research (hlm.255). New York: Longman. 
CENDEKIA, Vol. 12. No. 2 Oktober 2018

p-ISSN: 1978-2098; e-ISSN: 2407-8557

Http://cendekia.pusatbahasa.or.id; Email: cendekiaoslo@gmail.com

Center of Language and Cultural Studies, Surakarta, Indonesia

Suprapti, Sri. 2018. Meningkatkan Kemampuan Membaca Cerkak Melalui

Penguasaan Kosa Kata Bahasa Jawa Siswa Kelas VIII SMPN 8 Surakarta.

Cendekia (2018), 12(2): 111-128. DOI:10.30957/Cendekia.v12i2.522.

Dahar, R.W. 1989. Teori-Teori Belajar. Jakarta:Erlangga.

Departemen Pendidikan Nasional, Dirjen Dikdasmen. 2002. Pendekatan Kontekstual (ContextualTeaching and Learning (CTL)). Jakarta.

Depdikbud. 1995. Petunjuk Tekniks Mata Pelajaran Bahasa Indonesia. Jakarta.

Indrawati. S. 1996. Pengaruh Konteks Visual terhadap Pemahaman Wacana Murid Sekolah Dasar. Jurnal Imu Pendidikan, Agustus, III/3.

Indrawati, S. dan Alwi, Z. 2001. Upaya Meningkatkan Kemampuan Pemahaman Wacana melalui Model Pengembangan Skemata pada Siswa SLTPN Negeri 1 Indralaya. Forum Kependidikan, September 1/21.

Joyce, B. dan Weil, M. 1986. Models of Teaching. New Jersey: Prectice-Hall.

Madya, S. 1994. Panduan Penelitian Tindakan. Yogyakarta: Lembaga Penelitian IKIP.

Nurhadi \& Senduk. G. 2004. Pembelajaran Kontekstual dan Penerapannya dalam KBK. Malang: Universitas Negeri Malang.

Nurgiayantoro, Burhan. 1995. Teori Pengkajian Fiksi . Yogyakarta: Gajah Mada University Press.

Nurullah, Fitri Dian; Rusdiawan \& Nuriadi. 2018. Pembelajaran Menulis Cerpen Menggunakan Media Lagu Daerah Sumbawa pada Mata Pelajaran Bahasa Indonesia di Kelas X SMAN 1 Sekongkang. Lingua, 15(2):163-174.

DOI: 10.30957/lingua.v15i2.493.

Omaggio, Alice. 1986. Teaching Language in Context. Boston: Heinic Publishers.

Purnomo, M.E. 2006. Kurikulum Berbasis Kompetensi dalam Pembelajaran. Makalah disampaikan pada Seminar FKIP Unsri, 30 Januari 2006.

\section{LAMPIRAN: CERKAK SEPURE WIS MANGKAT DAN BOTOL PLASTIK}


CENDEKIA, Vol. 12. No. 2 Oktober 2018

p-ISSN: 1978-2098; e-ISSN: 2407-8557

Http://cendekia.pusatbahasa.or.id; Email: cendekiaoslo@gmail.com

Center of Language and Cultural Studies, Surakarta, Indonesia

Suprapti, Sri. 2018. Meningkatkan Kemampuan Membaca Cerkak Melalui

Penguasaan Kosa Kata Bahasa Jawa Siswa Kelas VIII SMPN 8 Surakarta.

Cendekia (2018), 12(2): 111-128. DOI:10.30957/Cendekia.v12i2.522.

\begin{abstract}
AKU nyawang arloji, jam 10 kurang limang menit. Saka speakere stasiun Tawang, Semarang keprungu lamat-lamat lagune Sony Jozh. Ora rinasa eluhku tumetes. Tembang kang mentas tak rungu mau malah njejuwing rasa pangrasaku. Kaya lagi nyemoni apa kang tak lakoni saksuwene iki. Gawang-gawang ing mripatku lelakon seminggu kepungkur ing stasiun iki ya ing kursi kang saiki tak lungguhi. Lelakon kang njalari ati kang sasuwene aku bebojowan mati dadi urip maneh.

Anggonku bebojowan cukup suwe nanging durung kaparingan momongan. Sepining batinku saya ngambar-ambra awit saploke ningkahan arang kadhing kumpul bojo merga dipisahake dening jarak. Aku nyambutgawe ing pamulangan luhur negri ing Semarang dene bojoku ngasta ana perguruan tinggi ing Bandung. Satemene ora kurang-kurang anggonku mbudidaya amrih bisa nyawiji karo bojoku nanging engga seprene durung bisa kaleksanan.

Rasa tresnaku marang mas Bas, bojoku, dadi luntur mbaka sethithik engga wusana ilang kasaput angin. Wis ora ana rasa apa-apa marang mas Bas sanajan yen pinuju ketemu ngana kae ya nindakake kaya satataning wong bebojowan. Rumangsaku rasane anyep tur ampang. Nanging ndilalah ana kedadeyan ora kanyana kang ndadekake atiku murub maneh. Yakuwi nalika ana tamu saka Jakarta sakperlu ngoreksi utawa monitoring marang penggaweyan kan dadi tanggung jawabku. Gawang-gawang kadadeyan seminggu kepungkur bali cumithak ana angen-angenku.

"Saya besok naik Kereta Gumarang dari Jakarta, sampai Semarang jam 13.00", ngono unine sms kang mlebu Hpku nalika iku.

"Baik Pak, kami usahakan untuk menjemput bapak ke stasiun", aku mbalesi.

Aku banjur ngajak pak Pur, sopir lembaga lan Bu Ati, staf kantor, supaya ngancani aku mapag rawuhe tamu saka Jakarta mau. Nanging najan wis meh sakjam anggonku ngenteni sepure meksa durung teka. Kamangka kudune sepur wis mlebu stasiun Tawang jam 13.00 nanging iki nganti jam 14.00 kok ya durung teka.

Nalika atiku goreh, saka speaker keprungu pengumuman menawa sepur sing dak antu-antu wis nyedhaki stasiun. "Perhatian untuk para penumpang, Kereta Ap Gumarang jurusan Jakarta - Semarang sebentar lagi akan memasuki stasiun."

Ora let suwe penumpang wis pating brubul metu saka gerbong. Nanging aku durung weruh Pak Pramujo, ya tamu saka Jakarta kuwi.

"Selamat siang Bu, selamat bertemu kembali."

Aku kaget, lha wong kene lagi menthelengi penumpang sing ndlidir metu saka stasiun kok mara-mara piyantune malah wis ana jejerku. Pak Pram ngathungake tangan ngajak salaman.

"Selamat siang Pak, selamat datang di Semarang. Semoga perjalanan Bapak tidak ada halangan apapun," aku mangsuli karo nampani astane.

"Langsung ke hotel saja Pak,sudah kami pesankan."

"Ya Bu, saya ngikut saja."

Wis rong dina papriksan berkas lan bukti lapangan katindakake dening Pak Pram. Maneka warna sing ditakokake, ewadene ya isih akeh sing dianggep kurang sampurna. Aku rada kaget karo sikepe Pak Pram. Dek semana nalika aku ngaturake proposal menyang Bogor sikepe cuek. Mesem wae ora. Nanging bareng saiki ketemu ana lapangan jebul akeh guyone lan nyumadulur. Kanca-kancaku sakantor melu seneng marang sikepe Pak Pram kang ora galak kaya pengawas sing uwis-uwis. Rong dina dudu wektu sing suwe tumrapku, nanging keconggah ngurupake genining atiku sing wis kebacut mati. Tuwuh rasa senengku marang Pak Pram sing kebapakan lan simpatik mau.

"Besok pulang ke Jakarta jam berapa Pak?" pitakone Bu Ati nalika Pak Pram wis rampung niti priksa berkas lapuran.

"Jam 10 siang Bu."
\end{abstract}


CENDEKIA, Vol. 12. No. 2 Oktober 2018

p-ISSN: 1978-2098; e-ISSN: 2407-8557

Http://cendekia.pusatbahasa.or.id; Email: cendekiaoslo@gmail.com

Center of Language and Cultural Studies, Surakarta, Indonesia

Suprapti, Sri. 2018. Meningkatkan Kemampuan Membaca Cerkak Melalui

Penguasaan Kosa Kata Bahasa Jawa Siswa Kelas VIII SMPN 8 Surakarta.

Cendekia (2018), 12(2): 111-128. DOI:10.30957/Cendekia.v12i2.522.

\begin{abstract}
"Baik Pak, besok saya siapkan mobil untuk mengantar Bapak," aku nyaut sebab minangka ketua proyek aku rumangsa duwe tanggung jawab marang panjenengane.

$* * *$

"Maaf Pak, tidak ada mobil kantor dan sopir yang nganggur. Terpaksa saya sendiri yang ngantar Bapak dengan sepedhah motor," kandhaku nalika Pak Pram wis samapta ing lobby hotel.

"Tidak apa-apa Bu, yang penting saya bisa sampai stasiun. Naik taksipun boleh jika terpaksa," wangsulane Pak Pram andhap asor.

Alon-alon motor tak lakokake tumuju stasiun. Sakdawane mlaku menyang stasiun ora akeh kang bisa dianggo bahan obrolan, luwih akeh meneng-menengane sinambi ngenam pikirane dhewe-dhewe. Nanging ya sakdawane mboncengke Pak Pram mau atiku saya ora karu-karuwan. Rumangsaku kaya lagi boncengan karo pacar. Tekan stasiun karepku arep ngeterake mlebu nanging dicandhet dening Pak Pram.

"Tidak perlu diantar sampai dalam Bu, cukup sampai disini saja."

"Tidak apa-apa Pak, wong saya juga sedang tidak ada kegiatan", kandhaku karo nyangking oleh-oleh kang arep digawa Pak Pram. Oleh-oleh pitukone kancakanca, makanan khas Semarang-an, kalebu bandeng dhuri lunak. Pak Pram mesem lan ngetogake aku melu mlebu peron.

Aku melu lungguh ngancani Pak Pram, nunggu sepur kang arep nggawa panjenengane kundur Jakarta. Ya ing ruwang tunggu iki akeh obrolan kang kawetu saka lambeku lan lesane Pak Pram. Sejatine mung ngobrol wajar, nanging cilakane malah dadi ora wajar tumrapku. Aku bola-bali nyawang pasuryane Pak Pram kanthi premati. Ya lagi ing stasiun iki aku bisa taneg ngematake pasuryane sing bagus jalaran sasuwene rong ndina ngancani panjenengane ora kober nggatekake. Tak sawang-sawang kok tambah nengsemake. Atiku kaya urip lan rasa pangrasaku mumbul maneh. Ati lan pangrasa kang wis lawas mati marga ora tau diopeni bojo.

Durung tutug anggonku ngobrol sinambi ngematake pasuryane Pak Pram dadak keprungu aba-aba yen sepur jurusan Jakarta arep mlebu stasiun. Pak Pram menyat siap-siap ana pinggir ril.

"Saya bawakan salah satu tasnya Pak," kandhaku karo nyangkingke tas oleh-oleh.

"Nggak usah Bu, saya sendiri bisa kok," wangsulane pak Pram karo mesem.

"Tapi kan repot," kandhaku.

Bareng sepure wis mlebu, aku lan Pak Pram munggah gerbong 2 nggoleki kursi $10 \mathrm{C}$. Sawise kursine ketemu lan barang wis diunggahke nduwur bagasi, aku nyawang penumpang kenya merak ati kang bakal dadi kancane Pak Pram lenggah. Ana rasa ewa ing atiku, yagene dudu aku sing njejeri penjenengane tumuju Jakarta?

"Hati-hati Pak, selamat jalan," kandhaku karo ngajak salaman.

"Ya Bu terima kasih atas semuanya dalam melayani saya selama disini," wangsulane Pak Pram karo nggegem tanganku kenceng.

"Sama-sama Pak, saya turun dulu," aku banjur mlaku metu saka gerbong.

Ing ruwang peron aku kepikiran marang wanodya kang ana jejere Pak Pram. Aku cemburu marang wanita kuwi nadyan ya ngrumangsani apa hak-ku nyujanani dheweke. Uthag-utheg aku nggrayahi HP ing njero tas, banjur ngetik sms. "Hati-hati di jalan Pak, jangan sampai dekat-dekat dengan cewek disamping Bapak lho."
\end{abstract}


CENDEKIA, Vol. 12. No. 2 Oktober 2018

p-ISSN: 1978-2098; e-ISSN: 2407-8557

Http://cendekia.pusatbahasa.or.id; Email: cendekiaoslo@gmail.com

Center of Language and Cultural Studies, Surakarta, Indonesia

Suprapti, Sri. 2018. Meningkatkan Kemampuan Membaca Cerkak Melalui

Penguasaan Kosa Kata Bahasa Jawa Siswa Kelas VIII SMPN 8 Surakarta.

Cendekia (2018), 12(2): 111-128. DOI:10.30957/Cendekia.v12i2.522.

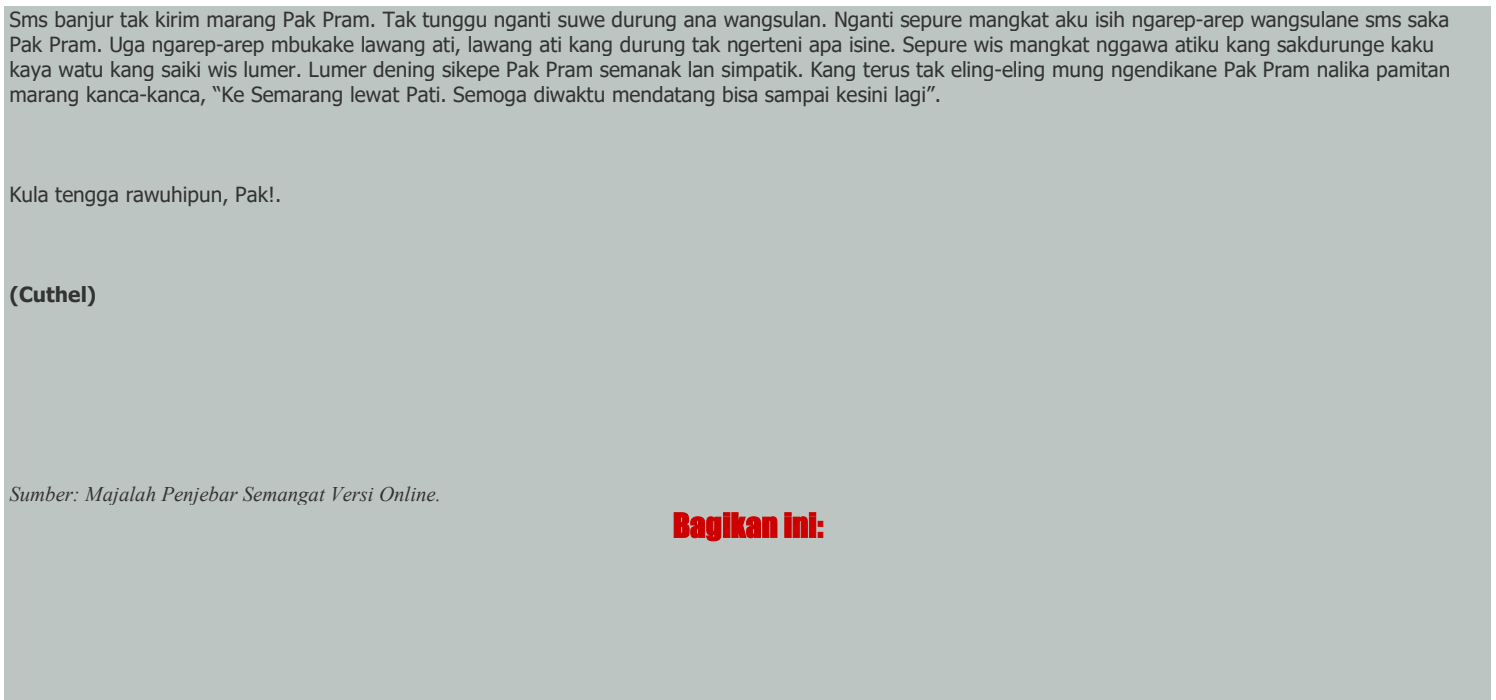

CERKAK 2: Botol Plastik

"Wis seger ya", ngono sapaku marang prawan setengah tuwa, bintang sinetron, sawise dheweke adus. Aku pancen nunggoni aneng kono. Nyawang olehe reresik awak. Wiwit sikatan, kramas, sabunan, nggebyur lan babar pisan umbah-umbah panganggo jerone. Prawan iku ora nggape, malah rengeng-rengeng lagune Didi Kempot. Awake katon weweg. Bubar adus krasa bingar, seger. Pancen sedina kuwi hawane krasa panas, sumuk. Dheweke ora wangsulan. Pancen sajake ora krungu panyapaku.

Sedina iki mau dheweke lagi prei, ora ana jadwal syuting. Wingi-wingi meh saben dina lunga, kadhang tekan bengi. Dadi bintang sinetron seri lan disiarake ana televisi saben dina. Istilahe kejar tayang. Pancen ya kesel temenan. Nanging asile lumayan. Sebab nadyan durung rong taun dikontrak dadi peran pembantu, saiki dheweke wis duwe sepedha-motor anyar. Sandhangane uga tambah akeh lan apik-apik modhele. Senadyan umure wis ngancik telungpuluh telu, nanging katon isih luwih enom. Awit awake kerumat.

Rumangsaku dheweke ya prawan lumrah. Praene ya manis, ora angkuh, ya ngerti unggah-ungguh. Ora gampang nesu, kepara sok ngalah. Apa maneh karo Rawi, siji-sijine adhine lanang, sing dadi bos pulsa tilpun seluler lan duwe kios cacah rolas. Nadyan wis bisa golek dhuwit dhewe, malah wis duwe sisihan lan anak lanang siji, Rawi kadhang isih sok mbeda mbakyune.

"Ndi mbak, tukon rokoke!"

"Jare dadi bos pulsa, dhuwit rokok bae sambat!" Mbakyune ganti melehake, nanging ya sambi tangane ngulungake rongpuluhan ewu rong lembar.

"Kesuwun, kesuwun. Dhuh, cen mbakyuku temenan."

"Ki daktambahi, tukokna mobil-mobilan kanggo anakmu!"

"Kesuwun. Alhamdulillah."

Wis ana patang pasaran aku manggon ing kamar-mandhi pribadhine, kang cedhak karo kamar paturone. Kadadeyan apa wae ing kono, sithik-akeh aku krungu lan ngerti. Kaya rong dina kepungkur, prawan kuwi - o, iya jenenge Wuri - dilamar wong saka Semarang. Jarene dhudha anak loro, sudagar barang rongsokan nanging sugih. Dhudha mau asring nonton lakon sinetrone, suwe-suwe kasengsem. Ning ya mbuh, kaya-kaya Wuri durung gelem.

Kuwi kabeh satemene kadadeyan biyen. Watara setengah taunan sing wis kliwat. Saiki aku wis ora manggon aneng kamare Wuri maneh. Aku wis pindhah. Dheweke ya wis lali marang aku. Lali temenan. Anggepe aku wis dadi titah tanpa aji. Aku uga babar blas wis ora nate ngerti kepriye nasibe, wis sida oleh jodho 
CENDEKIA, Vol. 12. No. 2 Oktober 2018

p-ISSN: 1978-2098; e-ISSN: 2407-8557

Http://cendekia.pusatbahasa.or.id; Email: cendekiaoslo@gmail.com

Center of Language and Cultural Studies, Surakarta, Indonesia

Suprapti, Sri. 2018. Meningkatkan Kemampuan Membaca Cerkak Melalui

Penguasaan Kosa Kata Bahasa Jawa Siswa Kelas VIII SMPN 8 Surakarta.

Cendekia (2018), 12(2): 111-128. DOI:10.30957/Cendekia.v12i2.522.

\begin{abstract}
apa durung. Elingku, ing sawijining sore, Wuri adus kramas. Aku luntak-luntak. Sakabeh sisa sing ana ing gembungku kasuntak entek. Awakku pegel kabeh sirahku krasa puyeng. Nanging isih lamat-lamat krungu swarane Wuri. Ing kamar mandhi rengeng-rengeng lagu lawas, Bujangan, anggitane band Koes Plus. ....... Begini nasib jadi bujangan, ke mana-mana, asalkan suka, tiada orang yang melarang ....." Apa iku ateges Wuri pancen isih seneng dhewekan, aku ora ngerti. Saka dayane cahya mau, aku kaya-kay kasedhot. Kaya-kaya dijunjung mabur sandhuwuring tlaga.
\end{abstract}

Sawise kuwi aku ora eling. Aku semaput. Aku ora krasa yen esuke disingkirake Wuri. Ora krasa yen banjur dilarung aneng kali Bogowonto. Ora krasa uga yen telung dina aku kenyut lining banyu. Nanging sajroning semaput aku malah ngimpi. Kaya-kaya aku nglangi aneng tlaga lendhut. Kuwi tlaga lendhute Bledhug Kuwu utawa tlaga lendhute Sidoarjo, ora pati cetha. Mung rumangsaku, aneng kono anggonku nglangi krasa abot. Napasku ngos-ngosan, krasa panas. Kayakaya arep ora kuwat. Nanging ndilalah kersaning Allah, dumadakan saka langit sisih wetan, sacedhaking lintang Panjer Esuk, kaya ana cahya nyemburat warna jingga. Saka dayane cahya mau, aku kaya-kaya kasedhot. Kaya-kaya dijunjung mabur sanduwuring tlaga. Mubeng-mubeng sawetara, ngliwati gunung Merapi, ngliwati Gunung Kelud dan Semeru. Sarwa cepet. Ngerti-ngerti mudhun aneng pucuking Gunung Agung ing pulo Bali. Rumangsaku, ing kono awakku dadi wangi. Dirubung kupu lan tawon madu. Nalika aku kepingin njegur aneng tlaga Kintamani, tan kanyana aku nglilir. Aku sadhar saka semaputku.

Ujare wong akeh, jare impen kuwi mung kembanging turu. Sawetara pangandikane para pujangga ana uga impen sing ngemu pralambang. Aku ora ngerti lan ora nate neges-neges apa impenku biyen. Mbuh pralambang, mbuh kembang turu. Nanging kabeh kang kadadeyan dumunung sanjabane pangiraku. Saiki aku lungguh aneng kursi empuk. Sakiwa tengenku kebak kembang paesan. Ngganda wangi, amarga kala-kala disemprot parfum. Ya saiki iki aku dadi pajangan aneng kothak kaca sajroning mall kutha Surabaya. Pancen nasibku kadidene cakra manggilingan. Tau kepenak kaya ing omahe Wuri. Tau ora rekasa nalika dilarung ing kali, campur rereged warna-warna. Ning begjaku, saka pinggir kali, aku diopeni dening tukang-batu sing bojone makarya dadi pengrajin boneka saka barang bekas. Awakku sing langsing diupakara, didandani, diklambeni, dibengesi lan liya-liyane. Pungkasane dadi boneka cantik, sing disenengi anake wong-wong sugih. Wah, rasane seneng tenan.

Urip aneng kono kanyata ora suwe. Aku dipundhut dening mbak Tery kanggo hadhiah tanggap-warsa putrine, sing ngancik patang taun. Mbak Tery kuwi bojone Om Trialdo, yaiku pemain bal saka Brasil sing dikontrak kumpulan bal-balan Bratasena FC. Wiwit kuwi aku meh saben dina ngancani Mirdha, prawan cilik sing tregil, yen melek meh ora tau leren anggone dolanan. Kadhang aku dijak nyanyi, njoged, utawa nyandiwara. Mirdha dadi ibu, aku dadi anake. Mangkono sadina-dinane.

Klakon setaun Om Trialdo ganti dikontrak kumpulan bal-balan Barito FC ing Kalimantan. Mirdha lan ibune melu pindhah mrana. Jalaran keburu-buru, ora kabeh barang-barang darbeke digawa. Sabageyan sengaja ditinggal, sabageyan ketriwal. Klebu aku dhewe, boneka cantik sing dumadi saka botol plastik, melu sing kesingsal. Esuk mau wis kesampar saka dhapur tekan luwangan uwuh. Awan mau kena panase sang surya tanpa bisa suwala.

Sore iki si Kacung, nom-noman tangga sing sok dikongkon resik-resik, klakon ngobong uwuh. Ateges ya babar pisan ngobong awakku. Awakku nglinthing kepanasen. Ora nganti seprapat jam wis dadi areng, dadi awu. Awakku sirna, musna. Kari sukmaku mbaleni impen lawas. Mabur. Sandhuwure gunung Merbabu, ngliwati gunung Kelud lan Semeru. Nanging ora tekan pulo Bali. Malah mengalor nyebrang segara, tumuju menyang Banjarmasin. Ngetutake sedulur sinarawedi, Mirdha, anake mbak Tery. Nanging ora suwe. Aku nglayang maneh, ngidul-ngulon. Ngliwati bengawan Solo lan kali Bogowonto. Sedhela mampir ana omahe tukang-batu sing nate nulungi awakku. Terus mangulon. Pungkasane tekan sawijining perumahan ing tlatah kutha Bogor. Tekan omahe Wuri sing anyar. Aneng petamanan mburi omah, dheweke lagi lungguhan karo sawijining priya bagus. Kekarone katon kaya Pranacitra lan Rara Mendut lagi padha pacelathon. Mbuh apa sing lagi pada dirembug. Mbuh! 